\title{
Gifted Education in Private Primary Schools in Hadhramout District, Yemen
}

\author{
Hussein S. M. Barabwd, Abu Y. A. Bakar, Noriah M. Ishak, Mohamed Y. M. Nor \\ Faculty of Education, Universiti Kebangsaan Malaysia, Bangi, Selangor, Malaysia \\ Email: yazid3338@ukm.edu.my
}

How to cite this paper: Barabwd, H. S. M., Bakar, A. Y. A., Ishak, N. M., \& Nor, M. Y. M. (2021). Gifted Education in Private Primary Schools in Hadhramout District, Yemen. Creative Education, 12, 329-348. https://doi.org/10.4236/ce.2021.122023

Received: December 23, 2020

Accepted: February 6, 2021

Published: February 9, 2021

Copyright (c) 2021 by author(s) and Scientific Research Publishing Inc. This work is licensed under the Creative Commons Attribution International License (CC BY 4.0).

http://creativecommons.org/licenses/by/4.0/

(c) (i) Open Access

\begin{abstract}
Gifted students require special services in schools that address their cognitive, physical, language, emotional, social, and academic needs. This study, therefore, investigates the extent to which gifted education is implemented in Private Primary Schools (PPS) in Hadhramout district in the Republic of Yemen from the perspective of schoolteachers. A descriptive quantitative approach was employed with data collected via a structured questionnaire developed by the researchers. This consisted of 36 items covering five domains: Identification of Gifted Students (IGS), Curriculum Materials (CM), Staff Development (SD), Evaluation of Gifted Students' Performance (EGSP), and Evaluation of Services of Gifted Students (ESGS). In this district, there were 60 PPS with 1500 teachers and more than 20,000 students from grade 1 to 9 . The sample consisted of 300 teachers $($ Female $=171$ and Male $=129)$. The results revealed that the extent of implementation of four domains, namely IGS, CM, EGSP, and ESGS, was at a low level. However, the extent of implementation of the SD domain was at an average level. Therefore, the overall extent of implementation of gifted education was low. This leads to two major recommendations. Firstly, PPS should focus on the implementation of gifted education to meet the needs of gifted students. Secondly, more robust research is required to investigate the implementation of gifted education in both private and public schools.
\end{abstract}

\section{Keywords}

Gifted Education, Private Primary Schools, Yemen

\section{Introduction}

The issue of gifted education has recently been at the forefront of educational debates (Friel, 2015; Erwin \& Worrell, 2012). The core value of education is that 
all children should be enabled to reach their full potential regardless of aptitude. Gifted students, therefore, need to be identified; this requires professionals who understand issues relating to giftedness, the wishes of such children, their desire for connection, their search for meaning, and their sensitivity, complexity, and intensity (Böttger \& Reid, 2015). Therefore, the core mission of education is to ensure that the educational needs of all students are met so that their potential can be fully developed (Wong, 2002). Consequently, gifted students need special education that addresses their extraordinary abilities and intelligence (Sumida, 2010). Without a deliberate search for the gifted and the provision of sensitive school programmes for gifted students (including underachievers), it will not be possible to provide successful and fair education for all gifted individuals. In the Republic of Yemen, one of the countries located in the Arabian Peninsula, gifted education has been a relatively new initiative in the country for the past 15 years and various gifted education programmes have been implemented in government schools in five governorates (Jarwan, 2005). Additionally, private schools have implemented several gifted programmes to meet their students' needs. However, limited research has been conducted to evaluate the effectiveness of these programmes.

Before proceeding with the current study, several terms need to be defined. Firstly, what is gifted education? This was defined by as "the schooling of students demonstrating some exceptional abilities" (Al-Ghawi, 2017: p. 1). It has also been defined by the policy of Grantsburg School District as providing “... the best possible educational experience for all students, enabling them to reach their full potential intellectually, academically, artistically, creatively, and socially" (Johnson, 1999: p. 13). The latter was employed as an operational definition for the term gifted education in this study.

Secondly, what exactly is giftedness? The term has been conceptualized in different ways and there is no internationally agreed definition. It is therefore difficult to find a consensus among scholars and practitioners working in the field of gifted education (Alqefari, 2010). One of the best-known definitions is provided by the US Department of Education (cited in Johnson, 1999: p. 4), which reads as follows: "...children and youth with outstanding talent perform or show the potential for performing at remarkably high levels of accomplishment when compared with others of their age, experience, or environment. These children and youth exhibit high-performance capability in intellectually, creative and/or artistic areas, possess an unusual leadership capacity, or excel in specific academic fields. They require services or activities not ordinarily provided by the schools. Outstanding talents are present in children and youth from all cultural groups, across all economic strata, and in all areas of human endeavor".

For the purpose of this study, the researchers employed the "Three-Ring Conception of Giftedness" developed by Joseph Renzulli which has received broad recognition among giftedness scholars (Renzulli, 1998). The "Three-Ring Conception of Giftedness" encompasses a number of interactions that contribute to giftedness, including personality and environmental factors, which have an 
effect on an individual's ability to be involved in creative and productive endeavors. Thus, gifted behavior reflects an interaction among three basic clusters of human traits, these clusters being above average (but not necessarily high) general and/or specific ability, high levels of task commitment (motivation), and high levels of creativity. Gifted children are those possessing or capable of developing this composite set of traits and applying them to any potentially valuable area of human performance (Renzulli, 2002). Figure 1 depicts the "Three-Ring Conception of Giftedness".

The three-ring conception of giftedness offers an operational definition that could be used by schools as the basis for identification that, in turn, leads to more targeted programming options for gifted students. Recent research related to the three-ring conception has focused on the infinite number of interactions that contribute to giftedness, including personality and environmental factors that have an impact on a person's ability to engage in creative and productive endeavors (Renzulli, 2002). Also, literature has shown that hence no single criterion should be utilized to recognize giftedness, those who have achieved recognition for their unique accomplishments and creative contributions possess three groups of traits namely above-average ability, task commitment, and creativity (Renzulli, 2002, 1998, 1975).

The above-average ability could be defined in two manners: general ability and specific ability. General ability indicates the capacity to process information, integrate experiences that lead to suitable and adaptive responses in new situations, and engagement in abstract thinking. For example, the general ability is like verbal and numerical reasoning, spatial relations, memory, and word fluency. On the other hand, the specific ability is the capacity to acquire knowledge, skill, or competence to perform in a specialized area. For instance, the skills of an archaeologist or mathematician would be considered specific ability skills. In general, Renzulli considered this is to be the top $15 \%$ to $20 \%$ of performance in any given area of human endeavor (Renzulli, 2002, 1998).

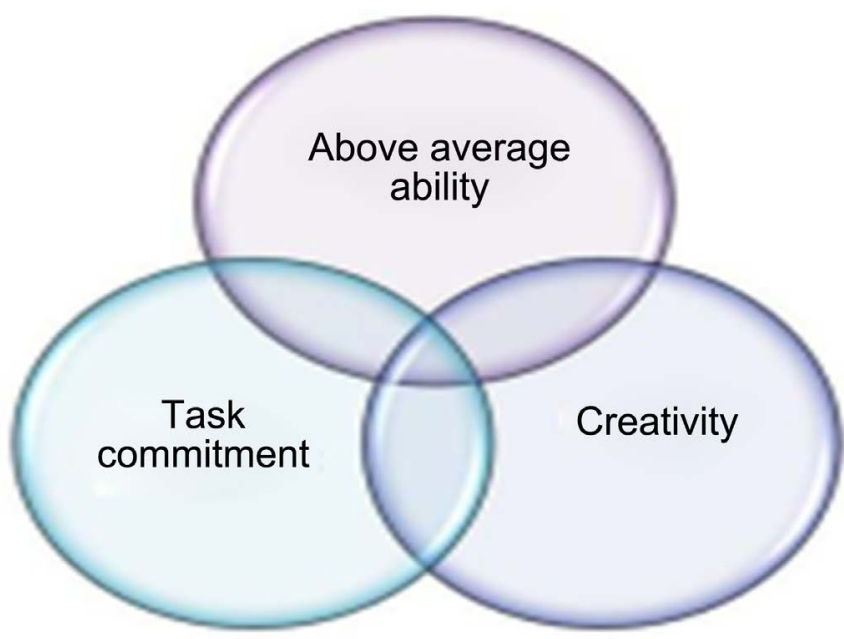

Figure 1. “Three-ring conception of giftedness”. Source: Renzulli (1998). 
Task commitment is the second cluster of traits that are consistently found in creative and productive persons shapes a refined or focused form of motivation that Renzulli has called it "task commitment". However, motivation is always defined in terms of a general energized process that triggers responses in organism; task commitment represents energy brought to bear on a particular problem (task) or specific performance area. The terms that are associated with task commitment are perseverance, endurance, hard work, practice, and confidence in one's ability to engage in significant work. Once again, these manifestations of task commitment are the result of chances, resources, and encouragement that are offered within the context of stimulating and interest-related learning situations (Renzulli, 2002, 1998, 1975).

Creativity is the third cluster of traits that characterizes gifted persons contains factors that have in the past been lumped together as creativity. It is not uncommon to see the words gifted, genius, and highly creative persons used interchangeably and synonymously. In three-ring conception, the term creative indicates the one who is identified for his/her creative accomplishments or persons who have a facility for generating several interesting and feasible ideas. It is crucial to consider that the inclusion of creativity creates a problem because of the relationship of creativity measurements and creative accomplishments. Given that creativity tests may not measure all domains of creativity, it is important to focus on alternative strategies to evaluate this complex manifestation of human behavior (Renzulli, 2002, 1998).

The purpose of this study was to investigate the extent to which gifted education is implemented in Private Primary Schools (PPS) in Hadhramout district from the perspective of schoolteachers. It focused on five specific domains: Identification Gifted Students (IGS), Curriculum Materials (CM), Staff Development (SD), Evaluation of Gifted Students' Performance (EGSP), and Evaluation of Services of Gifted Students (ESGS).

\section{Conceptual Framework}

This study employed the Schoolwide Enrichment Model (SEM) developed by Renzulli and Reis (1997) as its conceptual framework. SEM is a blueprint for school development in gifted education that enables every school to improve its own programmes by utilizing its own resources (Renzuli \& Renzulli, 2010; Gibson \& Efinger, 2001). SEM has been adopted in more than 2500 schools across the United States. Several studies have been conducted to investigate its impact on developing gifted education in the schools. The results of which have demonstrated its effectiveness (Burris, 2011).

For this study, the researchers focused on the Organizational Components of the SEM (Figure 2), namely identification instruments, curriculum materials, staff development, and evaluation instruments. This is because these are important for any gifted programmes in schools and are among those that have been cited in different studies as the main pillars for gifted education (Budair, 2018; VanTassel-Baska, 2005). 


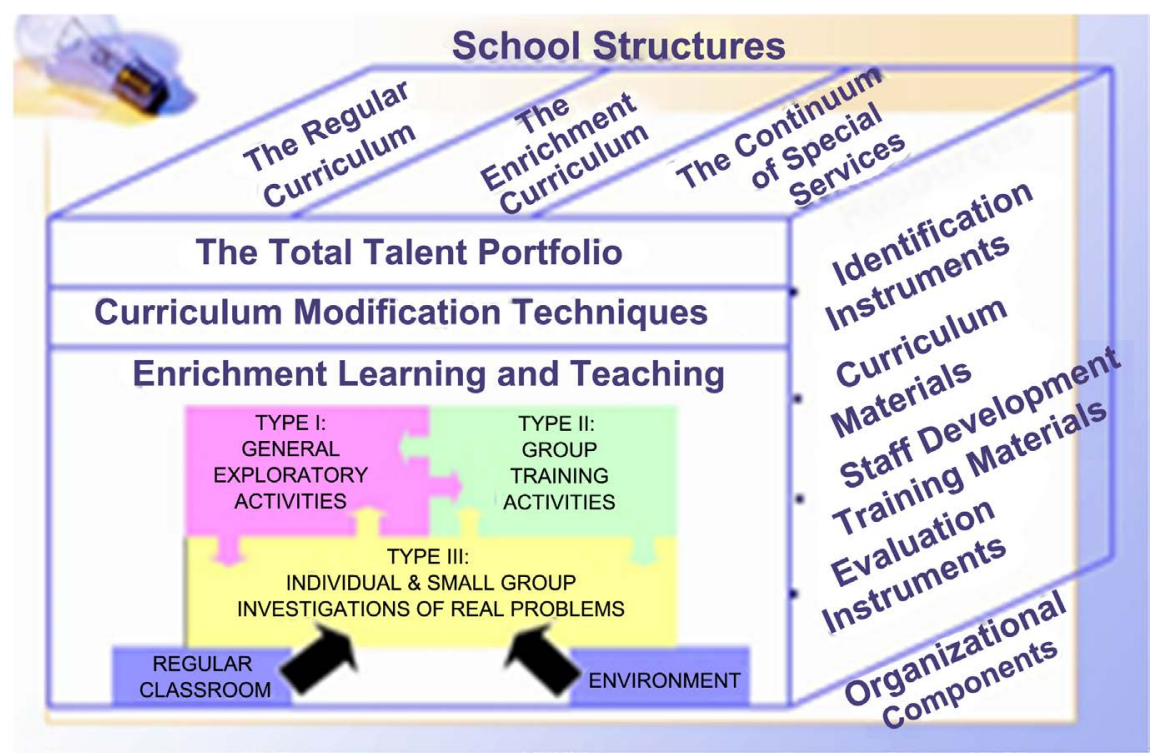

Figure 2. School wide enrichment model (SEM). Source: Renzulli \& Reis (1997).

\subsection{Identification of Gifted Students (IGS)}

To ensure an effective identification process, several measures, methods, instruments and multiple pieces of evidence have been designed especially for gifted students such as teacher, parent and peer nominations, and nonverbal measures (Al Qarni, 2010). However, standardized tests are usually insufficient to identify gifted minority and low-income students. This is because children need to answer verbal quantitative questions in order to obtain high scores. Furthermore, several intellectual minority children lack the basic skills of learning, such as reading and writing (VanTassel-Baska, Feng, \& Evans, 2007). Naglieri and Ford (2003) argue that those children if they had taken a non-verbal test of general ability, would have demonstrated high performance. Therefore, alternative evaluation tools such as performance-based tools and evaluation rubrics are required to assess individual growth.

Gifted students might also be difficult to identify because they exhibit different behavioral patterns (Jankiewicz \& Knyaginina, 2017). One of the issues impeding identification practices is the absence of adequate instruments with which to apply them. In some cases, identification instruments tend to limit the selection of gifted students due to the way they are applied, consequently they fail to identify all the capacities of such students. Even though there are standard tests that measure the intelligence quotient (IQ) of students and can indicate intellectual giftedness, this should not be considered the sole indicator. If a student has an intellectual quotient greater than 130, he/she is recognized as gifted. Conversely, if he/she scores from 115 to 130 , they are regarded as being above average (Jankiewicz \& Knyaginina, 2017). However, this test is not the only means available to measure intellectual giftedness. Psychologists also take into consideration personal conversations with students and their parents to identify high abilities (Bakar \& Brody, 2019). Furthermore, several scholars have found 
that the underrepresentation of minority students in gifted education programmes is the result of biased evaluation practices. However, an examination of the psychometric characteristics of scores on cognitive abilities, achievement tests, and rating scales do not support these claims.

Achievement tests also offer valuable information about students' academic performance. They are useful for teachers because they can corroborate teachers' initial judgments and encourage them to be adaptable, particularly when new items are produced, thus generating unbiased findings as evidence of high ability (Dimitriadis, 2010). In some countries, students are tested at different levels of schooling through standardized or public achievement tests. Student achievement in each test determines the type of educational facility that will then be offered to them (Isa, 1993).

In addition, Painter (1989) stated that the judgment of a highly skilled teacher is often accepted as the most reliable method of identifying a gifted student. However, there is no consensus among researchers regarding this claim. For example, Freeman (1998) found that teachers' judgements were not particularly accurate. He also identified several factors that can affect teachers' objective measurement of their students' abilities, such as the fact that their perceptions may vary.

It has also been argued that parents know their children better than teachers because they observe their children in different contexts. Furthermore, they have the opportunity to observe their children's development from birth. Nevertheless, parents can be biased and may overestimate their children's performance for several reasons. One benefit of parent nomination is that it allows a large number of children to participate in programmes searching for the gifted, thus testing children who would not otherwise be recognised by schools or teachers (Alqefari, 2010; Lee \& Olszewski-Kubilius, 2006). Therefore, parents need to play a major role in identifying gifted children from their informal observations as well as through communication with the school. The school also has a role to play in providing parents with a professional checklist to document their observations in a transferable, comparable, and quantifiable way (Emmanouilidou, 2007).

\subsection{Curriculum Materials for Gifted Students (CMGS)}

The curriculum is a fundamental element in each education system and guides both teachers and students during the teaching and learning process (Stephens \& Karnes, 2015). A specialized curriculum for gifted students is therefore fundamental. Compared to their peers, gifted students have special social and emotional needs (Phelan \& Allen, 2018; Bakar, 2017; Cavilla, 2016). The schools need to know how to facilitate better performance for each student which can be a challenging task, particularly in classrooms where there are several levels of ability. Usually, gifted students are not encouraged to perform to their highest capacity because they appear to be doing well. Furthermore, the normal curricu- 
lum does not challenge the high abilities of the gifted (Stephens \& Karnes, 2015). Although teaching gifted students has become a core part of education since it was first formalized, years of experience have not enabled the academic community to understand or even recommend best practices to the school staff who deal with gifted students on a daily basis.

Why does a specialized curriculum for gifted students matter so much? In a universe where the rapid expansion of knowledge has formed unheard of choices regarding what one can learn and several modalities within which one may learn, the conservation of time when learning has become ever more fundamental (VanTassel-Baska, 2013). One advantage gifted students have is the ability to learn faster than others; however, if this speed advantage is squandered on meaningless content, there is no clear advantage in the learning process (VanTassel-Baska \& Brown, 2009). Furthermore, a curriculum with a discipline orientation teaches learners to think and act like professional practitioners through procedures that are linked either to specific disciplines or to research and scholarship skills that are applicable across domains (Hockett, 2009). Consequently, school staffs are confused as to what the content of gifted students curriculum should be. Should it be the same as that received by everyone else, only at a faster pace? Should it be a totally different curriculum based on rapid mastery of the basics? Or should it be an integrated experience that interweaves disciplinary approaches, multiple subject areas, and different time frames for learning? These fundamental questions were answered by VanTassel Baska (2013) with the ambiguous statement "it depends".

Gifted students should receive an education worthy of their mental capabilities in an inclusive and clear manner from primary through to secondary school (Hockett, 2009). These settings support the usage of an integrated curriculum that grants flexibility in what it offers at different phases of development. This includes opportunities for mentorship, internship, and service-learning at secondary levels and independent and group project work at primary levels in addition to advanced instruction in both core and non-core content. As such, the gifted curriculum is an extension of the common core, with a value-added set of different emphases tailored to the needs of fast learners and an integrated set of experiences held together by common themes and ideas.

Various forms of curricula enable teachers in normal classrooms to meet and nurture gifted students' needs. These are: 1) curriculum differentiation based on modulation of the content, process, and products; 2) curriculum compacting, which involves removing mastered content or simplifying work due to students' ability to master it at a fast pace; 3) curriculum enrichment, which provides learners with opportunities to handle content that exceeds the regular curriculum in-depth and on a multidisciplinary basis; 4) curriculum acceleration, which is based on learners' ability to acquire knowledge and skills at a more rapid pace than their peers. This enables them to cover advanced content regardless of their age or grades through grade advancement, specific subject acceleration, honors classes, advanced placement classes, and early college entrance (Auld et al., 2000). 


\subsection{Staff Development (SD)}

Several studies emphasize preparing, qualifying, and training teachers across the world in gifted education (Budair, 2018; Mahmoud, 2012; Jarwan, 2008; Feldhusen \& Jarwan, 2000). Furthermore, all educators, administrators, counsellors, and other instructional support staff should increase their knowledge of gifted education. Jarwan (2005) reported that experts in the field of gifted education emphasize the fact that teaching staff are ranked at the top of all factors that contribute to the success of gifted and talented programmes. Therefore, the careful selection and training of staff are essential, both before and after service. From the previous discussion, it is clear that school staff should be trained in issues relating to gifted education and should be able to manage gifted students. In this context, the National Association for Gifted Children (NAGC) assigned ten standards of knowledge and skills teachers should possess to provide optimal services for gifted students. These standards center on being familiar, aware, and knowledgeable about giftedness, comprise of the following:

1) the foundations of gifted education;

2) development and characteristics of learners;

3) individual learning differences;

4) various instructional strategies;

5) learning environments and social interactions;

6) learners' language and communication skills;

7) developing effective instructional planning among teachers;

8) assessments utilized in the identification process, measuring students' progression, and evaluation of the programme;

9) ethical practices between teachers and learners and different methods and resources for ongoing professional development.

\subsection{Evaluation of Gifted Students' Performance}

Generally speaking, evaluation provides information about aspects of gifted education such as the identification process, learning progress, learning outcomes, and evaluation of programmes for gifted students in different domains Moreover, a differentiated evaluation protocol is fundamental in identifying gifted students' attainment of the desired progress and their high achievement in different subject areas with respect to the accountability and importance of the gifted programme. Preparation and proper training for national and international high stake examinations of a content-based curriculum are mandatory, even for gifted students. In addition, alternative evaluation instruments such as performance-based instruments and evaluation rubrics are fundamental for measuring individual growth (VanTassel-Baska, 2005).

In sum, the evaluation of giftedness is challenging due to the scope of its definition and the difficulty of measuring particular aspects such as creativity or originality (Veiga et al., 2014). There are some suggestions in the literature that, in addition to the cognitive aspects, some components are related to socio-emotional 
adjustment, indicating that a high level of cognition does not necessarily correspond to strong socio-emotional competency. However, there is currently no consensus on the emotional characteristics of gifted students (Veiga et al., 2014; Mendaglio, 2008).

\subsection{Evaluation of the Services for Gifted Students}

Services or programme evaluation is defined by Alkin et al. (2012: p. 16) as "the process of ascertaining the decision areas of concern, selecting appropriate information, and collecting and analyzing information in order to report summary data useful to decision-makers in selecting among alternatives". Evaluation is crucial for programme sustainability as it increases the accountability of developers by revealing to the public the success of the programme, the extent to which it achieves its goals, and its cost-effectiveness. Moreover, the process of evaluating the programme and services provided for the gifted in schools give directors and teachers the opportunity to review and improve this programme or services.

In his book "A guide for evaluating the programme for the gifted and talented", Renzulli (1975) recommended asking the following key questions to evaluate a gifted programme:

1) Did it do any good?

2) Was it worth the time and effort?

3) Was it worth the money?

4) Is it working as we expected?

5) Is this approach better than some other methods?

These are some of the questions being asked with increased frequency as schools pursue what sometimes appears to be the impossible dream of offering every learner the best possible learning environment for his or her particular needs. However, special education for those who are gifted is an essential part of any school programme that respects the principle of individual differences. It also reflects the competition for limited resources among all kinds of supplementary programmes that frequently causes the needs of the gifted to be relatively low on the list of educational priorities.

The main purpose of programme evaluation is to gather and analyze data that can be used to make the correct decisions about educational programmes. The evaluation should always be directed towards action that develops the provision for learners through the continuation, modification, or elimination of conditions that influence the learning process.

\section{Methodology}

To investigate the current status of gifted education in private primary schools (PPS), a quantitative approach was employed. The researchers developed a structured questionnaire consisting of 36 statements distributed across five domains: Identification Instruments (IGS), Curriculum Materials (CMGS), Staff 
Development (SDGE), Evaluation of Gifted Students' Performance (EGSP), and Evaluation of Services of Gifted Students (ESGS). To test the reliability of the questionnaire, Cronbach Alpha was computed using SPSS version 24 and was found to range between 0.846 and 0.922 . Table 1 presents all of Cronbach's alpha values that were higher than the recommended value of 0.60 (Hair et al., 2006). Regarding content reliability, the researchers showed the questionnaire to seven experts to confirm that the questionnaire could measure the targeted goals. There were a total of 60 PPS in Hadhramout district containing more than 20000 students from grade ( 1 to 9 ) and approximately 1500 teachers. The selected sample of teachers consisted of 300 teachers (Female $=171$ and Male $=$ 129 ), representing $20 \%$ of the overall population. Of the 300 questionnaires distributed, 260 were returned, giving a response rate of $86 \%$. Due to missing values, 20 questionnaires were excluded from the analysis and 13 cases were considered outliers. This left a total of 227 usable questionnaires, a response rate of $75 \%$. The data were analyzed using the Statistical Package of Social Sciences (SPSS) version 42. Means, standard deviations, and percentages were used to test the level of implementation of gifted education in these schools.

All 36 items of the questionnaire were scored using a 5-point Likert scale, to measure the respondents' level of agreement to each item of the five dimensions (all items were reported in the results and discussion section). Table 1 displayed the Cronbach Alpha values of each dimension of the questionnaires after the pilot test was administered.

\section{Results and Discussion}

Statistics can be broadly divided into descriptive statistics and inferential statistics (Kaliyadan \& Kulkami, 2019; Seltman, 2012). Descriptive statistics provide a summary of the sample being studied without drawing any inferences based on probability theory. Even if the ultimate goal of a study involves inferential statistics, descriptive statistics are still presented to provide an overview of the sample. When we describe the population using tools such as frequency distribution tables, percentages, and other measures of central tendency like the mean, we are therefore utilizing descriptive statistics. Conversely, when we employ a particular statistical test (e.g., T-Test, Mann-Whitney and U-test) to compare the mean

Table 1. Cronbach alpha values for the five questionnaire dimensions.

\begin{tabular}{llcc}
\hline \multicolumn{1}{c}{ Dimensions } & Code & N0. of Items & Cronbach Alpha \\
\hline Identification Instruments for Gifted Students & IGS & 8 & 0.846 \\
Curriculum Materials for Gifted Students & GMGS & 9 & 0.878 \\
Staff Development in Gifted Education & SDGS & 8 & 0.922 \\
Evaluation of Gifted Students' Performance & EGSP & 6 & 0.876 \\
Evaluation of the Services for the Gifted Students & ESGS & 5 & 0.892 \\
& Total & 36 & 0.909
\end{tabular}


scores and express this in terms of statistical significance, we are utilizing inferential statistics (Kaliyadan \& Kulkami, 2019). For this study, the results were classified into descriptive statistics relating to demographic characteristics and inferential statistics relating to the variables. Both types of results are discussed in the following sections.

\subsection{Demographic Characteristics}

Researchers often gather demographic data to characterize the sample of individual respondents or organizations in their studies. The data are reported narratively or in a table format, with frequencies used for both qualitative and quantitative studies. The demographic data are a fundamental part of the research and should be examined carefully. Therefore, readers should not skip these data to get directly to the results because demographic characteristics reveal information about subsets of the population at a particular point in time (Connelly, 2013). For this study, the targeted demographic characteristics were gender, age, qualification, specialization, and experience.

First, in terms of gender, out of 227 teachers, 132 were female (58\%) and 96 were male (42\%). Thus, the majority of PPS teachers were females, which is accepted in primary schools as females are considered to have a greater ability to teach children than males. Second, in terms of age, the respondents were divided into four categories. Most respondents were aged 20 - 30 (68.4\%) while the fewest number of teachers fell into lowest the category "aged more than 50 years". This reveals that the majority of teachers were young, which requires PPS to focus more on staff development. Thirdly, in terms of qualification, 183 out of 227 teachers had a bachelor's degree (80.3\%), which is a good qualification level, and 16 teachers had a secondary school qualification only (7\%). This percentage is considered acceptable in public primary schools where the percentage of teachers holding secondary school level qualifications is higher than in private schools, although no research to date has compared the qualifications of teachers in public and private primary schools. Fourthly, the academic specialization of teachers was categorized into two types: applied sciences and social sciences. The result reveals that almost 136 teachers (about $60 \%$ of the sample) specialized in applied sciences while 92 teachers (40\%) specialized in social sciences. Finally, in terms of teaching experience, the respondents were divided into five categories. The results indicate that $57.5 \%$ of teachers had less than 5 years of experience and just 5.3\% had more than 20 years' experience. This indicates that most teachers in PPS in Hadhramout district are junior teachers with little experience.

\subsection{Descriptive Statistics of Variables}

To measure the implementation of gifted education in PPS, five dimensions were assessed: IGS, CMGS, SDGE, EGSP, and ESGS. All items were measured on a five-point Likert scale ranging from " 1 " (strongly disagree) to " 5 " (strongly agree). To answer the research questions, the means, percentages, and standard 
deviation (SD) of each measurement scale was calculated. The results are discussed in the following sections for each dimension in turn.

\subsubsection{Identification of Gifted Students (IGS)}

To what extent is IGS implemented in PPS in Hadhramout district? Table 2 indicates that the highest means of 3.255 (65\%) and $3.233(64 \%)$ are for items 6 and 7 , respectively, namely "the teacher can nominate the students in the school to be served as gifted" and "there are multiple criteria used for identifying each category of giftedness". This indicates that the teachers are able to nominate gifted students for some of the gifted programmes provided by the PPS. It also indicates that some criteria were assigned to the gifted. To clarify the level of implementation of IGS, the following table presents the means, percentages, and standard deviations for each item.

By contrast, the lowest mean of 2.403 (48\%) is for item number 4, which states "there are intelligence tests such as Wechsler scales and the Stanford-Binet intelligence test" This result indicates that most PPS schools in Hadhramout district do not have particular tests or instruments with which to identify gifted students. However, several studies consider the identification of gifted students to be the first and most important procedure in gifted education (Barabwd \& Al-Hidabi, 2016; Chan et al., 2009). The overall level of implementation of IGS for all items was low with a mean value of 2.787 (55\%).

\subsubsection{Curriculum Materials for Gifted Students (CMGS)}

To what extent is CMGS implemented in private primary schools in Hadhramout district? To answer this question, the mean values, percentages, and standard

Table 2. Implementation of IGS: means, percentages and SDs.

\begin{tabular}{|c|c|c|c|c|}
\hline No. & Item & Mean & $\%$ & SD \\
\hline 1 & $\begin{array}{l}\text { There is an operational definition of a gifted student in your } \\
\text { school that acknowledges general abilities. }\end{array}$ & 3.168 & 63 & 1.1462 \\
\hline 2 & $\begin{array}{l}\text { There are ratings scales such as Renzulli scale that can be } \\
\text { used to rate the behavioral characteristics of gifted students. }\end{array}$ & 2.561 & 51 & 1.1345 \\
\hline 3 & $\begin{array}{l}\text { There are standardized tests that produce scores based upon } \\
\text { national norms, e.g. Stanford achievement tests. }\end{array}$ & 2.573 & 51 & 1.1934 \\
\hline 4 & $\begin{array}{l}\text { There are intelligence tests such as Wechsler scales and the } \\
\text { Stanford-Binet intelligence test. }\end{array}$ & 2.403 & 48 & 1.2149 \\
\hline 5 & $\begin{array}{l}\text { There are tests of creativity; for example, Torrance tests of } \\
\text { creative thinking. }\end{array}$ & 2.502 & 50 & 1.1850 \\
\hline 6 & $\begin{array}{l}\text { The teacher can nominate the students in the school to be } \\
\text { served as gifted. }\end{array}$ & 3.255 & 65 & 1.3159 \\
\hline 7 & $\begin{array}{l}\text { There are multiple criteria used for identifying each category } \\
\text { of giftedness. }\end{array}$ & 3.233 & 44 & 1.1609 \\
\hline 8 & $\begin{array}{l}\text { There is a systematic process for linking identification } \\
\text { procedures to offered programmes and services. }\end{array}$ & 2.822 & 56 & 1.1856 \\
\hline & Overall scores & 2.787 & 55 & 0.8295 \\
\hline
\end{tabular}


deviations (SD) were calculated for all items on the CMGS dimension as illustrated in Table 3.

As indicated in the table, the highest mean value of 2.982 (59\%) is for item number 17 which states "the curriculum of the subjects is modified beyond the standard curriculum to include challenge". This result indicates that PPS teachers modify the official curriculum to challenge those who are gifted. However, the percentage of those who do this (59\%) is fairly low. The lowest mean value of $2.5111(50 \%)$ is for item number 12 which states "in your school, there are curriculum materials for the gifted students in social studies". This reflects the lack of curriculum materials in social studies. Furthermore, the overall result for the CMGS dimension indicates that all the mean values are less than 3 .

The overall mean is 2.778 , indicating a low level of implementation of gifted education. The results for the CMGS domain suggest teachers believe there are no curriculum materials or other enrichment materials in their schools for gifted students in arts, mathematics, sciences, and social studies. As Van-Tassel Baska (2003) stated, many people think that the issue of the curriculum for the gifted is new; however, this issue has been prevalent in the field for approximately 40 years.

\subsubsection{Staff Development in Gifted Education (SDGE)}

To what extent is SDGE implemented in private primary schools in Hadhramout district? Table 4 presents the results for this question.

Table 3. Implementation of IGS: means, percentages and SDs.

\begin{tabular}{|c|c|c|c|c|}
\hline No. & Item & Mean & $\%$ & SD \\
\hline 9 & $\begin{array}{l}\text { In your school, there are curriculum materials for gifted } \\
\text { students in the arts. }\end{array}$ & 2.687 & 53 & 1.2171 \\
\hline 10 & $\begin{array}{l}\text { In your school, there are curriculum materials for gifted } \\
\text { students in mathematics. }\end{array}$ & 2.680 & 53 & 1.3041 \\
\hline 11 & $\begin{array}{l}\text { In your school, there are curriculum materials for gifted } \\
\text { students in science. }\end{array}$ & 2.745 & 55 & 1.2642 \\
\hline 12 & $\begin{array}{l}\text { In your school, there are curriculum materials for gifted } \\
\text { students in social studies. }\end{array}$ & 2.511 & 50 & 1.1692 \\
\hline 13 & $\begin{array}{l}\text { In your opinion, your curriculum materials help gifted } \\
\text { students to develop the ability to summarize important } \\
\text { information accurately. }\end{array}$ & 2.894 & 58 & 1.3624 \\
\hline 14 & $\begin{array}{l}\text { In your opinion, your curriculum materials help gifted } \\
\text { students to develop critical thinking skills. }\end{array}$ & 2.378 & 54 & 1.2129 \\
\hline 15 & $\begin{array}{l}\text { In your opinion, your curriculum materials help gifted } \\
\text { students to develop creative thinking skills. }\end{array}$ & 2.850 & 57 & 1.2390 \\
\hline 16 & $\begin{array}{l}\text { In your opinion, your curriculum materials help gifted } \\
\text { students to develop organizational skills. }\end{array}$ & 2.861 & 57 & 1.2056 \\
\hline 17 & $\begin{array}{l}\text { The curriculum of the subjects is modified beyond the } \\
\text { standard curriculum to include challenges. }\end{array}$ & 2.982 & 59 & 1.2427 \\
\hline & Overall scores & 2.778 & 56 & 0.8891 \\
\hline
\end{tabular}


Table 4. Implementation of SDGE: means, percentages and SDs.

\begin{tabular}{|c|c|c|c|c|}
\hline No. & Item & Mean & $\%$ & SD \\
\hline 18 & The school staffs know how to effectively teach gifted students. & 3.071 & 61 & 1.2245 \\
\hline 19 & $\begin{array}{l}\text { The school staffs have the skills to effectively teach gifted } \\
\text { students. }\end{array}$ & 3.107 & 62 & 1.1715 \\
\hline 20 & $\begin{array}{l}\text { The school holds professional training for general education } \\
\text { teachers to provide instruction to gifted students. }\end{array}$ & 3.199 & 64 & 1.2893 \\
\hline 21 & The school staffs can create a safe environment for all students. & 3.301 & 66 & 1.2175 \\
\hline 22 & $\begin{array}{l}\text { The school staff can create a challenging environment for } \\
\text { gifted students. }\end{array}$ & 3.230 & 58 & 1.2257 \\
\hline 23 & $\begin{array}{l}\text { The teachers can use appropriate pedagogies to teach gifted } \\
\text { students. }\end{array}$ & 3.216 & 62 & 1.2345 \\
\hline 24 & $\begin{array}{l}\text { The school trains the teachers in effective instructional } \\
\text { strategies to meet the needs of gifted students. }\end{array}$ & 3.279 & 65 & 1.2779 \\
\hline \multirow[t]{2}{*}{25} & The school staffs are aware of gifted students' characteristics. & 3.414 & 68 & 1.1427 \\
\hline & Overall scores & 3.225 & 64 & 0.9927 \\
\hline
\end{tabular}

As indicated in the table, the means of all the items related to SDGE are above 3. The highest mean of 3.4141 (68\%) is for item 25 which states "the school staff are aware of gifted students' characteristics". This result is satisfactory as being aware of gifted characteristics as is one of the methods used to identify gifted students. Once the teachers know these characteristics, it is easy for them to nominate those who are gifted in different fields to the suitable programmes offered by PPS. Conversely, the lowest mean value of 3.0705 (61\%) is for item 18 which states "the school staff know how to effectively teach gifted students". This result may shed light on the need for more staff development, especially regarding gifted education issues. The overall average for the SDGE dimension is 3.225 (64\%), which is an average level of implementation. The standard deviations for all the variables on the SDGE dimension range from 1 to 1.1692, which reveals acceptable variability within the data set. Thus, this result indicates that private primary schools provide some training for their staff in gifted education.

\subsubsection{Evaluation of Gifted Students' Performance (EGSP)}

To what extent is EGSP implemented in PPS in Hadhramout district? Table 5 presents the results for this question.

As indicated in the table, the highest mean of 2.840 (57\%) is for item 28 which states "there is an annual evaluation of student data to ensure that gifted students are reaching the desired proficiency levels in areas related to their identification". This indicates that annual evaluations of data related to the performance of students are conducted at a low level. The lowest mean value of $2.703(53 \%)$ is for item 29 which states "the school conducts regular evaluation for gifted students". This indicates a lack of regular evaluation of the performance of these students. The overall average for the EGSP dimension is 2.786 (55\%) which reflects a low level of implementation of the evaluation of gifted students' performance. 
Table 5. Implementation of EGSP: means, percentages and SDs.

\begin{tabular}{|c|c|c|c|c|}
\hline No. & Item & Mean & $\%$ & SD \\
\hline 26 & The school evaluates gifted students' outcomes. & 2.978 & 59 & 1.2027 \\
\hline 27 & $\begin{array}{l}\text { The school evaluates the academic growth of gifted } \\
\text { students. }\end{array}$ & 2.762 & 55 & 1.1771 \\
\hline 28 & $\begin{array}{l}\text { There is an annual evaluation of student data to ensure } \\
\text { that gifted students are reaching the desired proficiency } \\
\text { levels in areas related to their identification. }\end{array}$ & 2.805 & 56 & 1.1878 \\
\hline 29 & $\begin{array}{l}\text { The school conducts regular evaluation for gifted } \\
\text { students. }\end{array}$ & 2.596 & 52 & 1.1460 \\
\hline 30 & $\begin{array}{l}\text { There are several types of evaluation for gifted students } \\
\text { in your school. }\end{array}$ & 2.735 & 54 & 1.1197 \\
\hline 31 & $\begin{array}{l}\text { The evaluation practices are matched to the curriculum } \\
\text { objectives. }\end{array}$ & 3.230 & 64 & 1.1586 \\
\hline & Overall scores & 2.776 & 55 & 0.9261 \\
\hline
\end{tabular}

\subsubsection{Evaluation of Services for Gifted Students (ESGS)}

To what extent is ESGS implemented in PPS in Hadhramout district? Table 6 presents the results for this question.

The results for the ESGS dimension indicate that the highest mean value of $2.840(57 \%)$ is for item 34 which states "there is a clear linkage between the differentiation of the curriculum and evaluation for gifted students" This indicates a low level of linkage between the differentiation of the curriculum and the evaluation process for gifted students. The lowest mean value of $2.703(54 \%)$ is for item 35 which states "there is a design for evaluating gifted services in your school". The overall average for the ESGS dimension is 2.786 (56\%). This indicates that implementation of the evaluation of the services for gifted education is also at a low level.

\subsubsection{The Overall Result for All Dimensions}

The main question for this study asks to what extent gifted education is implemented in PPS in Hadhramout district in terms of IGS, CMGS, SDGE, EGSP and ESGS. The following table presents the overall result for all dimensions.

Four dimensions, namely IGS, CMGS, EGSP, and ESGS, have mean values of $2.787,2.778,2.856$, and 2.775 (55\%, 55\%, 57\%, and 55\%), respectively. This indicates a low level of implementation for these four dimensions. By contrast, the SDGE dimension reached a mean value of 3.225 (64\%) which indicates an average level of implementation. This suggests that PPS focus on training their staff in gifted education at an average level. This is useful because if the staffs are not qualified in gifted education they will not be able to educate the gifted students. However, the overall mean value for all five domains is 2.868 (57\%). This indicates clearly that the extent of implementation of gifted education in PPS in Hadhramout district is low. Table 7 presents the overall results for all five dimensions. 
Table 6. Implementation of ESGS: means, percentages and SDs.

\begin{tabular}{|c|c|c|c|c|}
\hline No. & Item & Mean & $\%$ & SD \\
\hline 32 & $\begin{array}{l}\text { The school conducts a regular evaluation of its services for } \\
\text { gifted students. }\end{array}$ & 2.740 & 55 & 1.1243 \\
\hline 33 & $\begin{array}{l}\text { The school conducts an appropriate evaluation of its services } \\
\text { for gifted students. }\end{array}$ & 2.821 & 56 & 1.1126 \\
\hline 34 & $\begin{array}{l}\text { There is a clear linkage between the differentiation of the } \\
\text { curriculum and evaluation for gifted students. }\end{array}$ & 2.841 & 57 & 1.0547 \\
\hline 35 & There is a design for evaluating gifted services in your school. & 2.704 & 54 & 1.1218 \\
\hline \multirow[t]{2}{*}{36} & The school provides an annual report on its gifted education. & 2.828 & 56 & 1.1566 \\
\hline & Overall scores & 2.786 & 56 & 0.9177 \\
\hline
\end{tabular}

Table 7. The overall level of implementation of gifted education.

\begin{tabular}{lcccc}
\hline \multicolumn{1}{c}{ Dimension. } & Acronym & Mean & $\%$ & SD \\
\hline Identification Instruments for Gifted Students & IGS & 2.787 & 55 & 0.8925 \\
Curriculum Materials for Gifted Students & GMGS & 2.778 & 56 & 0.8891 \\
Staff Development in Gifted Education & SDGE & 3.225 & 64 & 0.9927 \\
Evaluation of Gifted Students' Performance & EGSP & 2.776 & 55 & 0.9261 \\
Evaluation of the Services for the Gifted Students & ESGS & 2.786 & 56 & 0.9177 \\
& Total & 2.868 & 57 & 0.9310 \\
\hline
\end{tabular}

\section{Limitations of the Study}

One important limitation of this study is that the targeted respondents were from the teaching staff only. The administrative staffs were deliberately not targeted as it was felt teachers were the most knowledgeable with respect to answering the questions due to their work norms. Another limitation is that the results were limited to private primary schools only. The results for public primary schools in Hadhramout district, therefore, remain unknown.

\section{Conclusion}

Based on the results, it can be concluded that PPS in Hadhramout district implements gifted education at a low level, especially in relation to IGS, CMGE, EGSP and ESGS. SDGE, however, was implemented at an average level. This is because PPS provide some training workshops in gifted education for their instructional staff. Furthermore, SDGE is an important factor not only in developing gifted education but also in the identification of gifted students and determining an appropriate curriculum for them. Therefore, the recommendation for PPS is to devise a comprehensive policy or strategy for developing gifted education in all five domains in order to cover factors that are the most important in supporting this development. Additionally, because the results were based solely on the views of schoolteachers, the researchers recommend conducting a study investigating gifted education from the perspective of the ad- 
ministrative staff. Finally, research should also be conducted to investigate how gifted education can be developed in private primary schools.

\section{Acknowledgements}

Authors are grateful to the Faculty of Education, Universiti Kebangsaan Malaysia for supporting this research work via the provision of funding (Research Grant Code: GG-2019-079).

\section{Conflicts of Interest}

The authors declare no conflicts of interest regarding the publication of this paper.

\section{References}

Al Ghawi, M. A. J. C. (2017). Gifted Education in the United Arab Emirates. Cogent Education, 4, Article ID: 1368891. https://doi.org/10.1080/2331186X.2017.1368891

Alkin, M. C., Christie, C. A., \& Vo, A. T. (2012). Evaluation Theory: A Wider Roots Perspective ( $2^{\text {nd }}$ ed.). In M. C. Alkin (Ed.), Evaluation Roots: A Wider Perspective of Theorists' Views and Influences (p. 386). Thousand Oak, CA: SAGE.

Al-Makhalid, K. (2013). Primary Teachers Attitudes and Knowledge Regarding Gifted Pupils and Their Education in the Kingdom of Saudi Arabia. Doctoral Dissertation, Manchester: University of Manchester.

Al Qarni, M. A. (2010). Evaluation of Provisions for Gifted Students in Saudi Arabia. Wollongong: University of Wollongong.

Alqefari, A. (2010). A Study of Programmes for Gifted Students in the Kingdom of Saudi Arabia. PhD Theses, London: Brunel University London.

Auld, C., Brown, J., Duffy, M., Falter, N., Hammond, T., Jensen, D. et al. (2000). Promising Curriculum and Instructional Practices for High Ability Learners Manual. Lincoln, NE: Nebraska Department of Education.

Bakar, A. Y. A. (2017). Developing Gifted and Talented Education Program: The Malaysian Experience. Creative Education, 8, 1-11. http://dx.doi.org/10.4236/ce.2017.81001

Bakar, A. Y. A., \& Brody, L. E. (2019). A Counselling Framework for Meeting the Needs of Gifted Students in Malaysia. In S. Smith (Ed.), Handbook of Giftedness and Talent Development in the Asia-Pacific (pp. 1-20). Singapore: Springer. https://doi.org/10.1007/978-981-13-3021-6_47-1

Barabwd, H. S. M., \& Al-Hidabi, D. A. (2016). The Contribution of the Principals of Basic Education Schools in Identifying and Caring for Gifted Students in Mukalla City-Republic of Yemen. International Journal for Talent Development, 7, 173-200. https://doi.org/10.20428/IJTD.7.1.8

Böttger, H., \& Reid, E. E. (2015). Gifted Education in Various Countries of Europe. Slavonic Pedagogical Studies Journal, 4, 158-171.

Budair, S. (2018). Examining the Implementation of Gifted and Talented Pilot Program in ADEK's Public Schools. Dubai International Academic City: The British University in Dubai.

Burris, L. (2011). The Importance of School-Wide Enrichment Programs in Elementary 
School Settings. San Rafael, CA: Dominican University of California.

Cavilla, D. (2016). Taxonomy of Affective Curriculum for Gifted Learners. Orlando, FL: University of Central Florida.

Chan, D. W., Chan, L.-K., \& Zhao, Y. (2009). Twenty-Five Years of Gifted Education Research in Hong Kong 1984-2008: What Lessons Have We Learned. Educational Research Journal, 24, 135-164.

Connelly, L. M. (2013). Demographic Data in Research Studies. MEDSURG Nursing, 22, 269-270.

Dimitriadis, C. (2010). Developing Mathematical Giftedness within Primary Schools: A Study of Strategies for Educating Children Who Are Gifted in mathematics. PhD Theses, London: Brunel University London.

Emmanouilidou, K. (2007). Giftedness, Talent and Emotional Intelligence: Definitions, Identification and Associations between Types of Ability. Exeter: University of Exeter.

Erwin, J. O., \& Worrell, F. C. (2012). Assessment Practices and the Underrepresentation of Minority Students in Gifted and Talented Education. Journal of Psychoeducational Assessment, 30, 74-87. https://doi.org/10.1177\%2F0734282911428197

Feldhusen, J. F., \& Jarwan, F. A. (2000). Identification of Gifted and Talented Youth for Educational Programs. International Handbook of Giftedness and Talent, 2, 271-282.

Freeman, J. (1998). Educating the Very Able: Current International Research. London: Stationery Office.

Friel, N. (2015). The Cinderella of Education: Gifted and Talented Pupils, with a Focus on Double Exceptionality. Växjö: Linnaeus University

Gibson, S., \& Efinger, J. (2001). Revisiting the Schoolwide Enrichment Model-An Approach to Gifted Programming. TEACHING Exceptional Children, 33, 48-53. https://doi.org/10.1177\%2F004005990103300407

Hair, J., Anderson, R. E., Tatham, R. L., \& William, C. (2006). Multivariate Data Analysis (7th ed.). Upper Saddle River, NJ: Prentice Hall.

Hockett, J. A. (2009). Curriculum for Highly Able Learners That Conforms to General Education and Gifted Education Quality Indicators. Journal for the Education of the Gifted, 32, 394-440. https://doi.org/10.4219\%2Fjeg-2009-857

Isa, A. M. M. (1993). A Critical Study of Various Methods Used to Identify Intellectually Gifted Malay Children. Hull: University of Hull.

Jankiewicz, S., \& Knyaginina, N. (2017). The Legal Regulation of Instruments for Identifying and Supporting Talented (Gifted) Pupils and Students in Germany. Eastern European Journal of Transnational Relations, 1, 43-60.

Jarwan, F. A. (2008). Giftedness, Talent and Creativity. Amman: Dar Al-Fiker.

Jarwan, F. A. (2005). Schools and Academies for Gifted Students Project: General Framework (p. 45). Amman: Dar Al-Fiker.

Johnson, A. P. (1999). A Model Gifted Education Program for Elementary Schools: Process and Product. Mankato, MN: Minnesota State University, Center for Talent Development.

Kaliyadan, F., \& Kulkarni, V. J. I. (2019). Types of Variables, Descriptive Statistics, and Sample Size. Indian Dermatology Online Journal, 10, 82-86.

Lee, S. Y., \& Olszewski-Kubilius, P. (2006). Comparisons between Talent Search Students Qualifying via Scores on Standardized Tests and via Parent Nomination. Roeper Review, 28, 157-166. 
https://doi.org/10.1080/02783190609554355

Mahmoud, A. J. S. (2012). An Evaluation of the Competencies of Teachers of Gifted \& Talented Students of Professional Practice Adopted by the Council for Exceptional Children (CEC) in Jordan. Science Journal of Education, 1, 12-19. https://doi.org/10.11648/j.sjedu.20130101.13

Mendaglio, S. (2008). Dabrowski's Theory of Positive Disintegration. Scottsdale, AZ: Great Potential Press, Inc.

Naglieri, J. A., \& Ford, D. Y. (2003). Addressing Underrepresentation of Gifted Minority Children Using the Naglieri Nonverbal Ability Test (NNAT). Gifted Child Quarterly, 47, 155-160. https://doi.org/10.1177\%2F001698620304700206

Painter, F. (1989). Who Are the Gifted? Definitions, Identification and Provision. London: Able Publishing.

Phelan, D., \& Allen, P. (2018). Social and Emotional Learning Needs of Gifted Students. Minneapolis, MN: Walden University.

Renzulli, J. S. (2002). Emerging Conceptions of Giftedness: Building a Bridge to the New Century. Exceptionality, 10, 67-75. https://doi.org/10.1207/S15327035EX1002_2

Renzulli, J. S. (1998). The Three-Ring Conception of Giftedness. In S. M. Baum, S. M. Reis, \& L. R. Maxfield (Eds.), Nurturing the Gifts and Talents of Primary Grade Students. Mansfield, CT: Creative Learning Press.

Renzulli, J. S. (1975). A Guidebook for Evaluating Programs for the Gifted and Talented. Working Draft. Storrs, CT: University of Connecticut.

Renzulli, J.S., \& Renzulli, S. R. (2010). The Schoolwide Enrichment Model: A Focus on Student Strengths and Interests. Gifted Education International, 26, 140-156. https://doi.org/10.1177\%2F026142941002600303

Renzulli, J. S., \& Reis, S. M. (1997). The Schoolwide Enrichment Model: A How-to Guide for Educational Excellence. Mansfield, CT: Education Resources Information Center.

Seltman, H. J. (2012). Experimental Design and Analysis. Pittsburgh: Carnegie Mellon University.

Stephens, K., \& Karnes, F. (2015). Introduction to Curriculum Design in Gifted Education. Naperville, IL: Sourcebooks, Inc.

Sumida, M. (2010). Identifying Twice-Exceptional Children and Three Gifted Styles in the Japanese Primary Science Classroom. International Journal of Science Education, 32, 2097-2111. https://doi.org/10.1080/09500690903402018

VanTassel-Baska, J. (2013). Curriculum for the Gifted: A Commitment to Excellence. Gifted Child Today, 36, 213-214. https://doi.org/10.1177\%2F1076217513487351

VanTassel-Baska, J. (2005). Gifted Programs and Services: What Are the Nonnegotiables? Theory into Practice, 44, 90-97. https://doi.org/10.1207/s15430421tip4402_3

VanTassel-Baska, J. (2003). Introduction to Curriculum for Gifted and Talented Students: A 25-Year Retrospective and Prospective. In J. VanTassel-Baska \& S. M. Reis (Eds.), Curriculum for Gifted and Talented Students (pp. 23-33). Thousand Oaks, CA: Corwin Press.

VanTassel-Baska, J., \& Brown, E. F. (2009). An Analysis of Gifted Education Curriculum Models. In F. A. Karnes (Ed.), Methods and Materials for Teaching the Gifted (pp. 107-137). Waco, TX: Prufrock Press. 
VanTassel-Baska, J., Feng, A. X., \& Evans, B. L. (2007). Patterns of Identification and Performance among Gifted Students Identified through Performance Tasks: A Three-Year Analysis. Gifted Child Quarterly, 51, 218-231. https://doi.org/10.1177\%2F0016986207302717

Veiga, F. et al. (2014). Students' Engagement in School, Giftedness and Creativity: A Literature Review. I Congresso Internacional Envolvimento dos Alunos na Escola: Perspetivas da Psicologia e Educação. Portugal: Universidade of Lisboa.

Wong, K. (2002). Catering for the Needs of Gifted and Talented Students by Defining an Appropriate Curriculum. Hong Kong Teachers' Centre Journal, 1, 166-171. 